\title{
ПОЛІТИЧНА СПАДЩИНА СТЕФАНА СТАМБОЛОВА У ПАРТІЙНІЙ СИСТЕМІ БОЛГАРІї (1895-1920)
}

\author{
Д. В. Миколенко
}

\begin{abstract}
Миколенко Д. В. Політична спадщина Стефана Стамболова у партійній системі Болгарії (1895-1920). У статті розкривається вплив політики видатного болгарського державника, регента i прем’єр-міністра Болгарії Стефана Стамболова на функціонування партійної системи країни наприкінці XIX й упродовж перших двох десятиліть XX ст. До спадщини цієї постаті автор відносить специфічну диференціацію правоцентристських політичних сил, формування організацій вождистського типу, а також діяльність Народно-ліберальної «стамболовістської» партії, яка протягом тривалого часу займала одне із провідних місць у внутрішньому житті країни.
\end{abstract}

Ключові слова: Народно-ліберальна партія; «стамболовісти»; багатопартійність; вождізм.

Миколенко Д. В. Политическое наследие Стефана Стамболова в партийной системе Болгарии (1895-1920). В статье раскрывается влияние политики выдающегося болгарского государственника, регента и премьер-министра Болгарии Стефана Стамболова на функционирование партийной системы страны в конце XIX и в течение первых двух десятилетий XX в. К наследию этой фигуры автор относит специфическую дифференциацию правоцентристских политических сил, формирование организаций вождистского типа, а также деятельность Народнолиберальной «стамболовистской» партии, которая в течение длительного времени занимала одно из ведущих мест во внутренней жизни страны.

Ключевые слова: Народнолиберальная партия; «стамболовисты»; многопартийность; вождизм.

Mykolenko D. V. Political legacy of Stefan Stambolov in Bulgarian party system (1895-1920). The article deals with the influence of politics of the prominent Bulgarian statesman, regent and Bulgarian Prime Minister Stephen Stambolov on the functioning of the party system in the country in the late XIX ${ }^{\text {th }}$ and the first two decades of the $\mathrm{XX}^{\text {th }}$ century. To this political figure's heritage author includes specific differentiation of center-right political forces forming, organizations of authoritarian type and activity of the People's liberal "stambolovist" party, which for a long time had one of the leading places in the inner life.

Keywords: People's Liberal Party; "stambolovists"; multi-party system; leaderism.

Остання чверть XIX ст. пройшла для Болгарії під знаком становлення державності. Важливу роль у цьому процесі зіграв відомий політичний діяч країни Стефан Ніколов Стамболов (1854-1895 рр.). Протягом 1870-1878 рр. він брав участь у національно-визвольному русі проти турецької влади; після створення болгарського князівства (1878р.) неодноразово обирався депутатом Народних зборів; у 1879-1886 pр. був членом Ліберальної, а в 1892-1894 pр. - Народно-ліберальної («стамболовістської») партії (НЛП); з 1884 по 1886 р. перебував на посаді голови Звичайних народних зборів (ЗНЗ).

На політичну авансцену С. Стамболов зійшов у 1886 р. Саме тоді в країні відбувся державний переворот, організований проросійськи налаштованими офіцерами болгарської армії. Військові заради врегулювання відносин із Санкт-Петербургом вирішили відсторонити від влади князя Батенберга, який остаточно розчарував імператора Алєксандра III. С. Стамболов не підтримав заколотників, а здійснив контр-переворот з метою відновлення на троні законно обраного монарха. Перемігши у цьому протистоянні, він у 1886 i 1887 p. очолював Регентську раду - орган, створений після зречення престолу Алєксандра I Батенберга. На цій посаді С. Стамболов сприяв приходу на болгарський трон німецького принца Фердинанда Саксен-Кобург-Готського, а також обмеженню впливу Росії на внутрішні справи Болгарії. Останнє призвело до розриву двосторонніх дипломатичних відносин із Санкт-Петербургом.

Очолюючи протягом 1887-1894 рр. кабінет міністрів, С. Стамболов доклав чимало зусиль для скорішої адаптації у болгарському суспільстві неоднозначно сприйнятого громадськістю країни і міжнародною спільнотою новообраного князя. При цьому Росія та інші великі держави не визнавали Фердинанда законним монархом, наполягаючи на тому, що влада Болгарії порушила статті Берлінського трактату 1878 р., не узгодивши його кан- 
дидатуру з гарантами статус-кво на Балканах. Проросійські політичні угруповання - «цанковісти»* i «каравелісти» **, котрих підтримувала значна частина громадськості, вимагали детронізації Фердинанда. Для подолання спротиву опозиції прем’єр-міністр застосовував авторитарні методи боротьби. У результаті переслідувань Д. Цанков і деякі його прибічники залишили країну, а послідовники П. Каравелова майже призупинили діяльність після арешту їх лідера. Статус легальної опозиції під час прем’єрства С. Стамболова мали лише «радославовісти» ${ }^{* * *}$, які офіційно визнали Кобурга законним князем ${ }^{1}$.

1893 року, внаслідок помітної демократизації політичного режиму, ліберали, південноболгарські «з'єдністи»*** і колишні консерватори значно активізувалися. Згуртувавшись, вони спільними зусиллями розпочали боротьбу за відсторонення від влади «стамболовістів». Негласно це опозиційне об'єднання підтримував князь Фердинанд, який прагнув розширити свій вплив у державі та позбутися нав'язливої опіки прем'єр-міністра. Врештірешт монарх наважився скористатися своїм законним правом, наданим йому конституці$€ ю$ й відправив С. Стамболова у відставку. Останній не зміг цьому завадити, адже через інтриги Фердинанда залишився без підтримки армії, а тому був змушений перейти до активної опозиційної діяльності ${ }^{2}$. Надії колишнього регента і прем'єра на швидке повернення до управління державою обірвав терористичний акт, у результаті якого він загинув.

Період правління С. Стамболова залишив після себе значну спадщину - певну інерцію внутрішнього розвитку держави, задану під час свого перебування при владі. До того ж він мав чисельних послідовників - членів НЛП, які протягом тривалого періоду представляли одну $з$ провідних політичних сил країни ${ }^{3}$.

Неоднозначність в інтерпретації різних аспектів діяльності С. Стамболова притаманна i болгарській історіографії. На початку XX ст. з'явилися перші роботи, присвячені вивченню біографії політика. Його образ, створений істориками і публіцистами у цей період, визначався суперечливістю. Одні характеризували його як національного героя Болгарії інші називали узурпатором, диктатором і русофобом 5 . За часів Народної Республіки Болгарія, коли в науці домінувала марксистська методологія, його діяльність пов'язувалась із забезпеченням егоїстичних вузькокласових прагнень промислової і торгової буржуазії́. Після «оксамитової революції» 1989 р. С. Стамболов перетворився на одного із самих шанованих національних героїв, зробивших значний внесок у справу розбудови незалежної держави та встановлення проєвропейського вектора зовнішньої орієнтації Cофії․

Російська дореволюційна ${ }^{8}$ і радянська ${ }^{9}$ історіографії створили здебільшого негативний образ С. Стамболова, котрий встановив жорсткий авторитарний режим, переслідував опозицію та приніс багато нещасть народу Болгарії. Сучасні російські дослідники ${ }^{10}$ скорегували оцінку своїх передників стосовно діяльності лідера НЛП. Політика С. Стамболова розглядається ними переважно у контексті розбудови національної держави, а також розвитку економіки й соціальної сфери. При цьому частіше підкреслюються саме заслуги регента і прем’єр-міністра у перетворенні Болгарії на сучасну європейську державу.

Ïх західні колеги ${ }^{11}$ представляють С. Стамболова видатним діячем, котрий зумів кардинально змінити курс зовнішнього і внутрішнього розвитку Болгарії, модернізувавши іiі економіку та систему державної влади.

Отже, в історичній науці достатньо розгорнуто висвітлено більшість аспектів політики С. Стамболова, але їхня оцінка має суперечливий характер. На наш погляд, детальний аналіз результатів його діяльності для розвитку країни у довготривалій перспективі спроможний суттєво скорегувати усталений в науковій літературі погляд щодо ролі цієї особи в історії Болгарії.

* Прибічники Д. Цанкова - впливового болгарського політика, прем'єр-міністра країни у 1883 1884 pp., котрі 1884 р. вийшли із складу Ліберальної партії. У 1897 р. угруповання очолив С. Данев, а в грудні 1899 р. на її основі була створена Прогресивно-ліберальна партія.

* Політичне угруповання на чолі з П. Каравеловим, засноване у 1886 р. після чергового розколу Ліберальної партії. 31896 р. - Демократична партія.

*** Члени Ліберального клубу, а з 1895 р. - Ліберальної («радославовістської») партії; прибічники В. Радославова - прем'єр-міністра Болгарії у 1886-1887 pp.

**** Інша назва членів Народної партії Східної Румелії, створеної у 1879 р., яку вони отримали 1884 р. за свою активну позицію під час вирішення національного питання - об'єднання Південної і Північної Болгарії. 
Метою даної роботи є дослідження одного із проявів спадщини Стамболова у функціонуванні політичної моделі Болгарії кінця XIX і перших двох десятиліть XX ст. Нами розглянуто як діяльність державника вплинула на розвиток партійної системи країни.

Болгарські партії виникли на базі угруповань лібералів і консерваторів у перебігу роботи Установчих зборів 1879 року. Перші виступали за обмеження повноважень монарха. Згідно з їх позицією, основним суб'єктом верховної влади мав виступати не князь, а парламент. Вони ратували за розширення демократичних свобод в країні й наполягали на непорушності конституційного ладу. Консерватори ж дотримувалися протилежної думки. Проіснувавши на політичній арені до 1886 р., вони встигли сформувати два перших уряди, втім не змогли виграти жодних виборів. У квітні 1881 р. ця партія підтримала встановлення авторитарного режиму Алєксандра I Батенберга та скасування основного закону. Вказаними діями вона дискредитувала себе в очах громадськості та згодом остаточно припинила діяльність. Ідеологічно близькою до консерваторів була інша політична сила - південно-болгарська Народна партія. У другій половині 1880-х - на початку 1890-х років вона продовжувала діяти як самостійна організація.

Гостре протистояння навколо питань, пов'язаних із міжнародною орієнтацією країни, призвело у 1887 р. до розколу Ліберальної партії на декілька самостійних угруповань «радославовістів», «цанковістів», «каравелістів» і «стамболовістів». Таким чином, у період прем’єрства С. Стамболова у Болгарії сформувався прототип багатопартійної системи. При цьому до 1894 р. вона існувала лише формально. В умовах жорсткого авторитарного режиму повноцінною діяльністю мали змогу займатися лише ті політичні сили, котрі визнали Фердинанда законно обраним монархом - «стамболовісти» $\mathrm{i}$ «радославовісти». Інші виконували роль так званої нелегальної опозиції. Вони проводили підпільну роботу та фактично залишалися поза межами основних державних процесів ${ }^{12}$.

Незважаючи на статус, всі новостворені партії представляли собою принципово інший, у порівнянні зі своїми попередниками - лібералами і консерваторами - тип організацій. Перш за все їх відрізняв вождізм - орієнтація на постать лідера, котрий, як правило, забезпечував значну долю фінансування, суттєво впливав на ідеологічні принципи, розробляв стратегію і тактику боротьби за владу, тощо. Водночас вельми зменшилося вагоме раніше значення центрального бюро, оскільки функції цього керівного органу, котрий представляли найбільш впливові члени, зосередив у своїх руках вождь.

Новий різновид партій характеризувався також наявністю власних розгалужених мереж місцевих осередків, тоді як ліберали і консерватори мали у своєму розпорядженні на периферії обмежену кількість нечисленних представництв. Першими створили провінційні бюро по всій країні «стамболовісти» і «радославовісти», чим суттєво збільшили свій вплив у суспільстві. Після 1894 р. їхній приклад взяли на озброєння «цанковісти», демократи-«каравелісти» і «народняки»".

Наприкінці XIX ст. партійний спектр більшості європейських країн можна диференціювати за ідеологічним принципом, де консервативні політичні сили перебували на правому фланзі, ліберальні - у центрі, а соціалісти - ліворуч. Для Болгарії ж були притаманні деякі специфічні особливості. Серпневий переворот і контр-переворот 1886 р., а також період регентства і прем'єрства С. Стамболова сприяли розділенню більшості існуючих партій на русофілів, які вважали Кобурга незаконно обраним князем і ратували за зближення 3 Росією, та русофобів - поборників закріплення чинного глави держави на болгарському троні й обмеження впливу Санкт-Петербурга на внутрішню політику Софії.

Отже, головним чинником розмежування партій князівства стало визначення ними власного погляду на династичне питання і зовнішньополітичну орієнтацію, а не бажання наслідувати одну з трьох основних ідеологій. Наприклад, 1896 року, коли на базі угруповання «каравелістів» утворювалася Демократична партія ${ }^{13}$, прибічники П. Каравелова почали масово звертатися до свого лідера з проханням роз'яснити позицію щодо правлячої у Болгарії династії. На їхню думку, за умови офіційного визнання ними Фердинанда

* Одна $з$ найбільш впливових політичних сил наприкінці XIX - на початку XX ст. Заснована 1894 р. після падіння режиму С. Стамболова колишніми консерваторами князівства, південно-болгарськими «з'єдністами» та деякими членами інших угруповань. 
законним правителем, ідеологія демократів не буде відрізнятися від платформи інших ліберальних сил країни ${ }^{14}$.

Таким чином, одну з груп болгарських партій - русофілів - складали «цанковісти», «каравелісти», південно-болгарські «з'єдністи» (до 1894 р.) і «народняки»; до іншої русофобів - належали «стамболовісти», «радославовісти», младоліберали* (з 1904 р.). I хоча цю диференціацію можна вважати доволі умовною ${ }^{15}$, адже жодна 3 політичних сил країни не визнавала себе русофобською**, вона виявилася довготривалою, залишаючись актуальною протягом усього періоду князювання/царювання Фердинанда. Упродовж 1895-1918 рр. представники цих двох непримиримих таборів жодного разу не створили між собою проурядову коаліцію. Незважаючи на те, що 1899 року князь активно лобіював формування провладної більшості зі «стамболовістів», «каравелістів» і «цанковістів», у 1901 p. - зі «стамболовістів» і «цанковістів», а 1903 р. розглядав можливість утворення блоку «народняків» і «стамболовістів», всі його зусилля виявилися марними. Русофіли відмовилися співпрацювати з русофобами, остерігаючись втратити при цьому свій авторитет та підтримку електорату.

Варто відзначити і складні відносини між близькими за ідеологією партіями. 1899 року за ініціативи керівництва Ліберальної і Народно-ліберальної партій розпочався процес об'єднання двох політичних сил в одну потужну організацію. 27 січня/8 лютого було укладено угоду про загальну підтримку політики кабінету Д. Грекова - тогочасного лідера «стамболовістів», та започаткування видавництва спільного друкованого органу - газети «Нов век» ${ }^{16}$. Крім того, сторони домовилися про рівний розподіл чиновницьких посад і депутатських мандатів за результатами майбутніх виборів у Народні збори, а також про об'єднання своїх місцевих осередків з перспективою майбутнього заснування єдиної Ліберальної партії.

Проте реакція рядових членів окружних та околійних осередків «радославовістів» і «стамболовістів» із самого початку була настороженою, адже протягом 1887-1894 pр. між політичними силами неодноразово виникали конфлікти ${ }^{17}$. Пам'ять про пережите жорстке протистояння, а також непорозуміння під час розподілу місць в адміністративному апараті завадили об'єднанню. Зрештою 1/13 жовтня 1899 р. НЛП перейшла в опозицію до кабінету «радославовістів» на чолі з Т. Іванчовим.

Поза всяким сумнівом партіям Болгарії було притаманне сповідування характерних для Свропи ідеологій. При цьому в політичній системі країни явно домінували правоцентристи, чия ціннісна орієнтація знаходилася на перетині лібералізму і консерватизму ${ }^{18}$. До них належали «стамболовісти», «народняки», «цанковісти», «радославовісти» і демократи, які наприкінці XIX - на початку XX ст. змінювали один одного біля керма держави. Частина 3 них виявляла більшу схильність до консерватизму («стамболовісти» і «народняки»), другі віддавали перевагу націоналізму («радославовісти» та «младоліберали»), треті робили ставку на ліберальні цінності («каравелісти» $\mathrm{i}$ «цанковісти») ${ }^{19}$.

Всі вищевказані організації часто-густо виступали єдиним фронтом проти лівих партій, які за впливом явно поступалися своїм опонентам. Наприкінці XIX ст. лівоцентристів у князівстві представляли так звані «партисти» - Болгарська соціал-демократична партія та створена 1893 р. реформістська організація «союзисти» - Болгарський соціал-демократичний союз, котрі, як і більшість опозиційних політичних сил, діяли нелегально. 1894 року після падіння режиму С. Стамболова вони об’єдналися у Болгарську робітничу соціал-демократичну партію, однак 1903 р. під час засідань Х конгресу через ідеологічні розбіжності відбувся ії розкол на «тісних соціалістів» на чолі з Д. Благоєвим і «широких соціалістів» Я. Сакизова. «Тісняки» стояли на позиціях марксизму, революційного соціалізму й інтернаціоналізму та вважалися однією з перших радикальних марксистських партій, які відмежувалися від реформістської соціал-демократії. Їхні більш помірковані колишні однопартійці підтримували реформи та виступали за «широке розуміння марксизму», «широку» діяльність серед усіх верств суспільства і «широкі» критерії членства в партії.

* Члени Младоліберальної партії - «тончевісти» - політична сила, яка 1904 р. на чолі з юристом Д. Тончевим відокремилася від Ліберальної партії В. Радославова.

** За часів прем'єрства С. Стамболова та після його смерті Народно-ліберальна партія позиціонувала себе захисницею національних інтересів, політичною силою болгарофільського спрямування. 
Наприкінці 1899 р. під час розгортання руху за скасування натуральної десятини в князівстві утворилася ще одна партія лівоцентристського спрямування - Болгарська землеробська спілка, котра представляла інтереси найчисельнішої соціальної категорії населення країни - селян. Заснована як професійно-економічна та просвітницька організація, вже наступного року під керівництвом Я. Забунова вона вперше взяла участь в общинних виборах, а 15/28 січня 1901 р. - в парламентських, отримавши 12 депутатських місць в XI ЗНЗ. III з’їзд, що відбувся восени 1901 р. в Софії, задекларував ії політичний характер та нову назву - Болгарська землеробська народна спілка. Тривалий час ця політична сила не мала чіткої програми дій. Пропонуючи різні варіанти соціально-економічних реформ на селі, вона поступово зуміла перетворитися на одну з провідних партій країни, яку 3 1904 р. очолив А. Стамболійский ${ }^{20}$.

Фланг лівоцентристів останніми у нашому переліку поповнюють представники лівого крила демократів-«каравелістів». Упродовж 1903-1905 рр. вони остаточно оформилися в окрему силу - Радикально-демократичну партію, яка на чолі з Н. Цановим ратувала за впровадження прогресивного податку, республіканську форму правління, повне самоврядування в усіх галузях суспільного життя, відмову від збройних сил та інші кардинальні перетворення.

Виникнення на початку другої половини 1880 -х років багатопартійності у Болгарії стало результатом жорсткого внутрішньополітичного протистояння в період регентства С. Стамболова. Надалі варто розглянути причини, що призвели до її остаточного закріплення.

Зазвичай на партійну систему кожної окремо взятої держави впливає порядок обрання депутатів законодавчого органу влади. 31879 р. по 1913 р. у Болгарії діяв мажоритарний варіант обрання майбутніх членів парламенту. Згідно з теорією відомого французького соціолога і політолога М. Дюверже, подібна практика стимулює формування двопартійності $^{21}$, проте в умовах Болгарії спостерігалася прямо протилежна тенденція - партійний спектр країни ставав все більш строкатим. Так, з 1911 по 1920 р. дев'ять, а то й десять політичних сил регулярно делегували своїх членів у парламенти XV, XVI, XVII i XVIII-го скликань.

Скоріш за все, подібна ситуація була визначена кількома чинниками. Один із них особливість формування Ради міністрів, яка закріпилася під час прем’єрства С. Стамболова. У Болгарії монарх призначав уряд, а згодом під нього міністрами штучно формувалася парламентська більшість. Механізми здобуття таких «перемог» на виборах тривалий час відшліфовувалися кабінетом Стамболова. Згодом ці методи брали на озброєння наступні уряди країни, у тому числі представлені опонентами «стамболовістів». Мажоритарна виборча система дозволяла не найпопулярнішій партії, отримавши не найбільшу кількість голосів, створити найчисельнішу фракцію у Народних зборах. Стабільні електоральні уподобання наприкінці XIX - на початку XX ст. були характерними для болгар у незначній мірі, тому кожна, навіть новозаснована політична сила, мала можливість втрутитись у конкурентну боротьба за владу. Це стимулювало істеблішмент до започаткування все нових і нових організацій.

Перебуваючи в опозиції, всі без винятку правоцентристські партії демонстрували типову стратегію поведінки. Вони намагалися у будь-який спосіб дискредитувати провладну силу в очах громадськості, але при цьому, вказуючи на певні вади політики уряду, найчастіше апелювали не до народу, а до князя/царя, розраховуючи отримати від нього дозвіл на формування чергового кабінету міністрів ${ }^{22}$. Ліві ж сили, у свою чергу, часто критикували не лише дії чинного уряду, а й глави держави, пропонуючи різні варіанти кардинальних реформ політичної системи, у тому числі скасування інституту монархії. Вони прагнули заручитися підтримкою певних соціальних категорій населення та не сподівалися на сприяння Фердинанда.

Боротьбу за владу в Болгарії у ті часи можна охарактеризувати як «кожен за себе». Необхідно відзначити лише деяку синхронність дій правоцентристських (ліберальних і консервативних) сил в їхньому прагненні відстоювати непорушність основ існуючого політичного режиму та протиставити себе лівим організаціям соціалістичного або радикального спрямування ${ }^{23}$. Опозиційні й провладні коаліції були нестійкими, часто вони носили формальний характер та залежали від певної кон'юнктури. 
Строкатий партійний спектр - це також результат функціонування у Болгарії політичних сил нового вождистського типу. Перші подібні організації були створені 1886 р. - «стамболовісти» і «радославовісти». 1894 року розпочала діяльність Народна партія, а 1899 р. - Прогресивно-ліберальна «цанковістська» ${ }^{24}$. Авторитаризм, притаманний таким політичним силам, заважав вільній внутрішній конкуренції у боротьбі за лідерство, перешкоджав відкритому обговоренню програм і статутів. Здебільшого всі основні питання, пов'язані з функціонуванням організації, вирішував очільник та обмежене коло його найближчих соратників. Саме тому часто-густо конфлікти й протистояння серед членів тієї чи іншої партії, які виникали внаслідок незадоволення діяльністю лідера, призводили не до зміни вождів або компромісу, а до порушення єдності та створення нових організацій. Наприклад, 1899 р. не згодне 3 політикою уряду К. Стоїлова і позицією правлячої Народної партії угруповання К. Величкова відмежувалося від «народняків» та приєдналося до «цанковістів».

1900 року через непорозуміння між В. Радославовим і Т. Іванчовим намітився розкол у лавах «радославовістів». За версією газети НЛП «Нов век», причиною суперечностей стали побоювання діючого керманича організації втратити лідерство у Ліберальній партії, адже наділений владою тодішній голова уряду Т. Іванчов мав достатній вплив, аби очолити Центральне бюро 25 .

Схожий процес відбувався і в середовищі «цанковістів» у 1902-1903 рр., коли одне угруповання згуртувалося навколо постаті С. Данева, інше ж об'єднали впливові політики Д. Попов і М. Сарафов ${ }^{26}$. В останніх двох випадках партії все-таки зберегли свою цілісність, а от 1904 р. від «радославовістів» остаточно відкололися прибічники Д. Тончева, утворивши Младоліберальну партію; у 1905-1906 рр. демократи-«каравелісти», незадоволені діяльністю лідера А. Малінова, сформували окрему Радикально-демократичну партію.

Вождізм багато в чому визначав і долю НЛП, яка після загибелі свого першого лідера і до 1920 р., коли об’єдналася з «радославовістами» і «тончевістами», відігравала помітну роль у політичних процесах країни ${ }^{27}$.

1895 року головою Центрального бюро НЛП було обрано Д. Петкова. Проте колишній градоначальник Софії і сподвижник С. Стамболова не вважав себе політиком першого ешелону, достатньо відомим серед електорату всієї країни. Крім того, до нього з недовірою ставився Фердинанд, що унеможливлювало для «стамболовістів» отримання шансу на створення Ради міністрів. Саме тому Д. Петков добровільно поступився посадою більш досвідченому й авторитетному однопартійцю Д. Грекову, котрий в уряді С. Стамболова тривалий час працював керівником різнопрофільних міністерств. Пройшовши етап реорганізації, НЛП зберегла найхарактерніші свої особливості. Вона залишалася політичною силою вождистського типу, коли на практиці більшість рішень щодо ії діяльності приймалися визнаним ідейним керівником - головою Центрального бюро, і лише у деяких випадках - спільно з його найближчим оточенням. Агітаційно-пропагандистська риторика «стамболовістів» свідчила про те, що вони, як і раніше, робили ставку на тісну співпрацю 3 монархом та підтримку правлячої династії.

1897 року Д. Греков, через власне бажання більше уваги приділяти професії адвоката, залишив посаду голови Центрального бюро НЛП. Лідером партії знову став Д. Петков. Але 1899 р. після отримання від князя пропозиції сформувати уряд він вдруге очолив «стамболовістів» та залишався керівником цієї політичної сили до своєї смерті в 1901 р.

Вказані зміни очільника Центрального бюро багато в чому були визначені стратегією поведінки Д. Петкова. Цей політик цілком міг претендувати на формальне лідерство у НЛП, оскільки мав значний авторитет серед однопартійців, проте в інтересах політичної сили поступився своїми амбіціями.

Д. Петков повернув собі юридичний статус керманича партії у 1901 р. і виконував обов'язки голови Центрального бюро до 1907 р. Протягом цього періоду він встиг заручитися не тільки широкою підтримкою соратників, а й довірою з боку князя. Останнє дозволило йому очолити Міністерство внутрішніх справ у 1903-1907 рр., зайняти посаду міністра громадських робіт і шляхів сполучення у 1905-1907 pp., а також керівника виконавчого органу у 1906-1907 pp.

13/26 лютого 1907 р. внаслідок збройного нападу Д. Петков загинув. Ця трагедія не минула безслідно для НЛП - серед «стамболовістів» поглибилися протиріччя у зв'язку з 
необхідністю обрання голови Центрального бюро. На позачергових зборах найближчий соратник попереднього лідера Н. Генадієв заявив права на лідерство у політичній силі. За нього віддала голоси більшість присутніх членів партії. Однак делегати із Пловдива на чолі з I. Андоновим і Т. Гатєвим та голова Софійського обласного бюро Добрі Петков разом зі своїми прибічниками голосували проти кандидатури Н. Генадієва і врешті-решт не визнали його новим керівником організації ${ }^{28}$. Свою позицію вказані політики пояснювали тим фактом, що у 1891 р. тодішній редактор пловдивської газети «Балканска зора» Н. Генадієв нерідко критикував діяльність уряду С. Стамболова, щоправда, уникаючи нападок особисто на прем'єр-міністра. Не згладжувало спогади навіть його швидке (наступного року) переорієнтування на «стамболовістські» позиції. Негативне сприйняття нового лідера НЛП деякими соратниками по партії також було визначене тим, що Н. Генадієв не зумів заручитися підтримкою Фердинада у своєму прагненні отримати посаду прем’єр-міністра.

Поступово у середовищі «стамболовістів» сформувалося опозиційно налаштоване по відношенню до лідера крило, яке очолювали пловдивські партійні функціонери I. Андонов і Т. Гатєв. Усвідомлюючи, що змістити Н. Генадієва буде вкрай важко, ці політики почали виступати 3 критикою вождізму та пропозиціями змінити систему управління політичною силою шляхом скасування посади голови Центрального бюро, розподіливши його повноваження між іншими інститутами - членами Вищої партійної ради і секретарем організації. Проте наміри опозиції залишалися нереалізованими, адже переважна більшість «стамболовістів» продовжувала підтримувати свого лідера.

Ситуація змінилася 1915 року. Тоді внаслідок загострення внутрішніх протиріч НЛП остаточно розкололася на два угруповання. Н. Генадієв несподівано почав виступати за приєднання Болгарії до Антанти - воєнно-політичного блоку Росії, Англії і Франції. Це відбувалося всупереч позиції Фердинанда, тогочасного кабінету міністрів В. Радославова і значної частини членів НЛП на чолі з міністром громадських робіт, шляхів сполучення і благоустрою Добрі Петковим, які віддавали перевагу зближенню з Німеччиною та Австро-Угорщиною 29 .

Щоб довести правильність власної позиції «генадієвісти» і «петковісти» наводили різні аргументи, при цьому кожне угруповання спиралося на політику засновника НЛП С. Стамболова. У своїх виступах досвідчений оратор Н. Генадієв переконував слухачів, що перший лідер «стамболовістів» в умовах Першої світової війни не вагаючись розпочав би співпрацю з Лондоном, Парижем і Петербургом, адже цього вимагали національні інтереси Софії. Д. Петков і його прибічники наголошували на неприпустимості укладання союзу з Росією, адже це суперечило основним принципам НЛП та могло призвести до втрати партією авторитету і підтримки відданих прихильників ${ }^{30}$.

Після завершення Першої світової війни «стамболовісти» знову об’єдналися навколо фігури Н. Генадієва, якого звільнили 3-під варти. «Петковісти» після арешту їхнього лідера у листопаді 1919 р. змушені були шукати можливості для примирення з «генадієвістами». Однак відставка кабінету В. Радославова, поразка Болгарії та ії союзників у війні, зречення Фердинанда престолу на користь свого сина Бориса, кардинальна зміна політичних уподобань населення на користь лівоцентристських партій - все це зумовило трансформацію стратегії і тактики НЛП. Політична сила не користувалася достатньою підтримкою у суспільстві, аби претендувати на владу, тому змушена була шукати союзу з ідеологічно близькими організаціями. 16/29 листопада 1920 р. разом з «радославовістами» $\mathrm{i}$ «тончевістами» вона влилася у Націонал-ліберальну партію. Дещо раніше 24 жовтня/6 листопада «народняки» і «цанковісти» утворили Об'єднану народно-прогресивну партію. Розмежування правоцентристських сил на русофобів і русофілів, яке закріпилося під час регентства і прем'єрства С. Стамболова, лягло в основу формування нових організацій консервативного і ліберального ідеологічного спрямування.

На відміну від Народно-ліберальної, Націонал-ліберальна партія представляла собою політичну силу не вождистського типу. Основні рішення щодо ії діяльності ухвалювали конгрес і Вища рада ${ }^{31}$.

Незважаючи на те, що «генадієвісти» $\mathrm{i}$ «петковісти» свого часу по-різному інтерпретували цілі та завдання НЛП, вони досягли компромісу під тиском відповідальності за збереження існуючого у Болгарії соціально-економічного і політичного устрою в умовах зростання популярності лівоцентристських сил. 
Останній лідер «стамболовістів» Н. Генадієв і його соратники продовжили свою кар'єру в складі Націонал-ліберальної партії. 1923 року більшість ії членів підтримали червневий переворот, зміщення уряду А. Стамболійского, приєднання до правоцентристського Демократичного зговору (союзу Демократичної, Радикально-демократичної і Об'єднаної народно-прогресивної партій та Народного зговору*), отримавши завдяки цьому посаду міністра правосуддя** у сформованому кабінеті на чолі з А. Цанковим. Н. Генадієв виступив проти таких кроків з боку однопартійців. 16/29 вересня він створив нову опозиційну політичну силу - Народна єдність, та намагався згуртувати навколо неї електорат відстороненої від влади і фактично знищеної Болгарської землеробської народної спілки. 17/30 жовтня 1923 р. політика було вбито. Терористичний акт, унаслідок якого він загинув, здійснили представники Внутрішньої македонської революційної організації, однак прибічники Н. Генадієва звинувачували в скоєному лідерів Демократичного зговору, вважаючи їх замовниками злочину. У відкритому листі до послідовників покійного відомий публіцист П. Генадієв характеризував свого старшого брата як істинного продовжувача справи засновника НЛП ${ }^{32}$, а член партії Народна єдність Г. Юртов назвав загиблого «гідним сином болгарського народу» та поставив в один ряд із С. Стамболовим, Г. Вилковичем, X. Белчевим і Димитром Петковим - видатними державниками, котрі постраждали від рук противників через діяльність в інтересах Батьківщини ${ }^{33}$.

Таким чином, політика С. Стамболова визначила особливості функціонування партійної системи Болгарії наприкінці XIX - на початку XX ст. По-перше, жорстке протистояння за часів його регентства і прем'єрства заклало основи багатопартійності, яка у більш-менш усталеному вигляді проіснувала до кінця світової війни. По-друге, дихотомія русофіли русофоби, котра також склалася в епоху першого правління кабінету «стамболовістів» у 1887-1894 рр. була визначальною в ідеологічній ідентичності правоцентристських сил країни. По-третє, витоки процесу формування партій вождистського типу з розгалуженою системою місцевих представництв беруть свій початок з 1886 р., коли були організувані дві перші організації з вказаними особливостями - «стамболовісти» і «радославовісти».

Важливу роль в системі державної влади Болгарії у 1895-1920 рр. відігравали безпосередні продовжувачі політики С. Стамболова, носії його ідейних принципів - представники Народно-ліберальної партії. У 1899, 1903-1908 і 1913-1918 рр. вони брали участь у формуванні урядів. Перебуваючи в опозиції, визначали настрої громадян країни. Члени цієї політичної сили, конкуруючи між собою за першість і вплив в організації, застосовували спадщину С. Стамболова - ідеї, прагнення та переконання цього непересічного державника задля обгрунтування власної правоти, доцільності того чи іншого політичного кроку.

${ }^{1}$ Танкова В. Южно-българските съединисти в условията на Стамболовия режим (1887-1894) // Исторически преглед. - 1992. - № 11. - С. 146-159.

${ }_{2}^{2}$ Мах Р. Из българските бурни времена. - София, 1992. - С. 118. 1986

${ }^{3}$ Попов Ж. Народно-либералната (стамболовистката) партия в България, 1903-1920. - София,

${ }^{4}$ Радев С. Строителите на съременна България: Регенство. София, 1990.

${ }_{5}^{5}$ Маджаров М. От самовластие към свобода и законност. София, 1936.

${ }^{6}$ Митев $T$. Политическата обстановка в първите години на Стамболовия режим и българските социалисти (1887-1891 г.) // Исторически преглед. - 1981. - № 2. - С. 52-74.

${ }^{7}$ Пантев А. Стефан Стамболов в часа на равносметка // Епохи. - 1994. - № 1. - С. 7-18.

${ }^{8}$ Овсяный Н.Р. Болгария и болгары. - Санкт-Петербург, 1900; Погодин А.Л. История Болгарии. - Санкт-Петербург, 1910; Ястребовъ Н.В. История болгарского народа / Н. В. Ястребовъ, П. А. Лавров. - Петроградъ, 1916.

${ }^{9}$ Гримм Э. К истории русско-болгарских отношений // Новый восток. - 1924. - Кн. 5. - С. 68-85; Сидельников С.И. Авантюра русского царизма в Болгарии (1878-1896 гг.) // Учёные записки Ленинградского государственного университета. - 1939. - № 36. - Вып. 3. - С. 145-180.

* Політична сила, створена як опозиційна уряду А. Стамболійського організація 1/14 жовтня 1921 р. безпартійними викладачами Софійського університету - А. Цанковим, П. Стайновим, Д. Мішайковим та іншими. Одним із ії засновників був також син колишнього лідера НЛП Д. Грекова дипломат і публіцист А. Греков, котрий став першим керівником партії.

** її зайняв адвокат Б. Смілов. 
${ }^{10}$ Гришина Р. Лики модернизации в Болгарии (бег трусцой по пересеченной местности). - Москва, 2008; Косик В. Размышления о судьбах Болгарии, Стефана Стамболова, государственности // Человек на Балканах. Государство и его институты: гримасы политической модернизации (последняя четверть XIX - начало XX вв.). - Санкт-Петербург, 2006. - С. 117-124.

${ }^{11}$ Perry D. Stefan Stambolov and the Emergence of Modern Bulgaria, 1870-1895. -Durham, 1993; Black $C$. The establishment of constitutional government in Bulgaria // Princeton studies in history. - Vol. 1. - Princeton, 1985. - P. 275-290.

${ }^{12}$ Миколенко Д.В. Правоцентристські партії у системі влади Князівства Болгарії (кінець XIX початок ХХ ст.). - Харків, 2008. - С. 25.

${ }^{13}$ Български исторически архив при Национална библиотека «Св. св. Кирил и Методий», ф. 395 «Петко Каравелов» (далі - БИА НБ «Св. св. Кирил и Методий»), оп. 1, а.е. 77, л. 18-21.

${ }^{14}$ БИА НБ «Св. св. Кирил и Методий», ф. 395 «Петко Каравелов», оп. 1, а.е. 77, л. 18.

${ }^{15}$ Миколенко Д.В. Про доцільність застосування термінів «русофіли» та «русофоби» при характеристиці зовнішньополітичної орієнтації правоцентристських партій Болгарії кінця XIX - початку ХХ ст. // Вісник Харківського національного університету імені В.Н. Каразіна. - 2007. - № 762: Серія «Ітсорія».- Випуск 39. - С. 166.

16 Димитьр Петков и народната либерална партия. - Пловдив, 1910. - С. 102; БИА НБ «Св. св. Кирил и Методий», ф. 638 «Димитьр Петков», оп. 1, а.е. 11-12, 15.

${ }_{17}$ Миколенко Д. Диференціація ліберальних і консервативних партій Болгарії на межі XIXXX століть: спроба кластерного аналізу // Дриновський збірник/Дриновски сборник. - Т. 2. - Харків-Софія, 2008. - С. 181.

${ }^{18}$ БИА НБ «Св. св. Кирил и Методий», ф. 395 «Петко Каравелов», оп. 1, а.е. 77, л. 22.

${ }^{19}$ Маковеикая Т.Ф. Буржуазный парламентаризм в Болгарии: становление и развитие (от освобождения страны от османского ига до ее вступления в первую мировую войну) // История и культура Болгарии. - Москва, 1981. - С. 86.

${ }^{20}$ Дюверже М. Политические партии / Пер. с франц. - М., 2000. - С. 211.

${ }^{21}$ Йоцов Я. Буржуазная демократия в Болгарии 1879-1923 гг. // Etudes historiques. - Vol. 5. - Sofia, 1970. - Р. 391.

${ }^{22}$ Нов век. - 1908. - 22 юли.

23 Програми, програмни документи и устави на буржоазните партии в България 1879-1918/ Съст.: В. Николова и Д. Саздов. - София, 1992. - С. 371

${ }^{24}$ Нов век. $-1900 .-1$ ноември.

25 Живков С. Прогресивнолибералите на власт. Хомогенният кабитет на д-р Стоян Данев (декември 1901 - май 1903) // История. - 2010. - № 5-6. - С. 70.

${ }^{27}$ Миколенко Д.В. Правоцентристські партії у системі влади Князівства Болгарії (кінець ХІХ початок XX ст.). - Харків, 2008. - С. 67.

28 Попов Ж. Народно-либералната (стамболовистката) партия в България, 1903-1920. - София, 1986. - C. 37.

${ }^{29}$ Кермекчиев А. Генадиев пред съда на народно-либералите. - София, 1915. - С. 6.

30 Там само. - С. 7.

31 Попов Ж. Народно-либералната (стамболовистката) партия в България, 1903-1920. - София, 1986. - C. 57.

${ }^{32}$ Генадиев П. Отворено писмо до почитателите и последователите на покойния ми брат Никола Генадиев и членовете на партията Народно единство. - София, 1931. - С. 33.

33 Д-р Н. Генадиев. Годишнина от убийството му / Под ред. на В. Савов, П. Думанов. - София, 1924. - С. 6. 